IZA DP No. 5490

The Transition from Work to Retirement

Werner Eichhorst

February 2011 


\title{
The Transition from Work to Retirement
}

\author{
Werner Eichhorst \\ IZA
}

\section{Discussion Paper No. 5490 \\ February 2011}

\author{
IZA \\ P.O. Box 7240 \\ 53072 Bonn \\ Germany \\ Phone: +49-228-3894-0 \\ Fax: +49-228-3894-180 \\ E-mail: iza@iza.org
}

Any opinions expressed here are those of the author(s) and not those of IZA. Research published in this series may include views on policy, but the institute itself takes no institutional policy positions.

The Institute for the Study of Labor (IZA) in Bonn is a local and virtual international research center and a place of communication between science, politics and business. IZA is an independent nonprofit organization supported by Deutsche Post Foundation. The center is associated with the University of Bonn and offers a stimulating research environment through its international network, workshops and conferences, data service, project support, research visits and doctoral program. IZA engages in (i) original and internationally competitive research in all fields of labor economics, (ii) development of policy concepts, and (iii) dissemination of research results and concepts to the interested public.

IZA Discussion Papers often represent preliminary work and are circulated to encourage discussion. Citation of such a paper should account for its provisional character. A revised version may be available directly from the author. 
IZA Discussion Paper No. 5490

February 2011

\section{ABSTRACT}

\section{The Transition from Work to Retirement}

The European Employment Strategy has set the goal of raising the retirement age of workers in the EU through a strategy of "active ageing". Yet despite some progress over the last decade, empirical data show persistent diversity across EU member states. Institutional arrangements of social and labor market policies can be seen as the core factors behind cross-national diversity. Hence, institutional change is crucial to explain structural changes. The paper tries to assess the role of supranational policy initiatives and national politicoeconomic factors in shaping the transition from work to retirement in EU member states which is still governed by the national political economy. Taking the German case as an example in point, the paper shows the dynamic interaction between policy changes, in particular in benefit systems and activation, and changes in the approach of firms and workers to early retirement. Policy changes influence actors' behavior in the medium run and open up opportunities for subsequent reforms.

JEL Classification: J14, J26

Keywords: $\quad$ early retirement, older workers, Germany, European Employment Strategy

Corresponding author:

Werner Eichhorst

IZA

P.O. Box 7240

53072 Bonn

Germany

E-mail: eichhorst@iza.org 


\section{The Transition from Work to Retirement}

\section{Introduction}

Raising the employment rate of older workers and postponing labor market exit has been a recurrent topic in both national and supranational discourse in the European Union. In particular, the EU has adopted a strategy of "active ageing", combining better labor market integration of older workers with increased participation in lifelong learning. This has become a core pillar of both the Lisbon Strategy and the European Employment Strategy in order to enhance social integration, economic growth and productivity as well as to counter the consequences of demographic ageing. Most explicitly, the EU has set ambitious quantitative targets to be achieved by 2010 as well as an elaborate monitoring process of EU member states' action.

This article assesses the current situation of older workers in EU labor markets and identifies different paths towards a better labor market integration of older workers by indicating the decisive role of labor market and welfare state institutions. Taking the changes in retirements policies in Germany as an example, main drivers of reforms are identified thereby assessing the relative role of supranational influences stemming from the European Employment Strategy and the Lisbon Strategy on the one hand and national politico-economic factors influencing core parameters for the employment of older workers on the other hand. The German policy sequence revoking an entrenched policy of early retirement is used as a case to exemplify the dynamics of institutional factors influencing the transition to retirement.

\section{Towards a longer working life? Trends in EU member states}

Regarding the employment of older workers in Europe - what has changed over the last decade? Figure 1 shows the evolution of the standard EU indicator of employment rates of older workers aged 55 to 64 between 2000 and 2009. Over time, most countries have achieved an increase in the employment of older workers by around 10 percentage points, so that at least the EU-15 countries could actually move close the 2010 Stockholm target of a 50 percent EU-wide employment rate of older workers. Yet the degree to which workers aged 55 and older are integrated into the labor market continues to vary across countries. Concerning the EU target, only four countries had already achieved a sufficient employment level of older workers as of 2009 (Sweden, Denmark, the UK and Portugal). Although 2009 was a year of crisis in most EU member states, nine further countries were able to meet 
this target - Estonia, Cyprus, Finland, the Netherlands, Latvia, Lithuania and Ireland, but also Germany - while Portugal experienced a slight drop. However, some Southern and Central European Countries such as Malta, Poland, Hungary, Italy, and also Continental European countries such as Belgium and France still lag behind significantly in both terms of level and trend.

Figure 1: Employment rates of older workers, 2000 and 2009

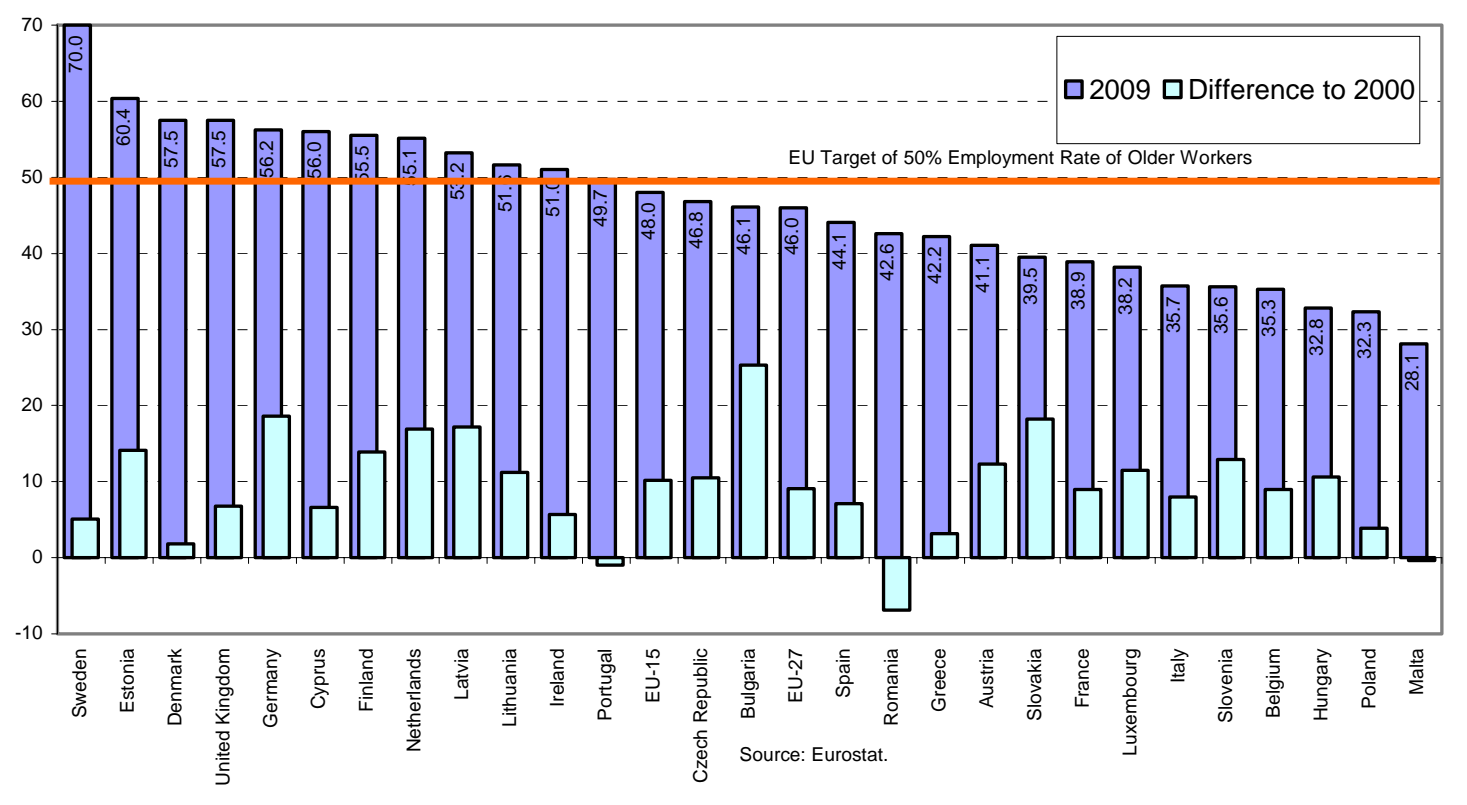

This general trend is confirmed by data on the actual retirement age in EU member states, which is to be raised by five years according to the Barcelona target, i.e. from an average of 60 to 65 . Between the early years of the last decade and the latest available data, retirement ages have been increasing by about 1.5 years on average. Again, there are large differences amongst EU member states, which are basically related to institutional features of the welfare state. With regard to some Central and Eastern and Continental European countries, progress towards later retirement has been rather limited. 
Figure 2: Actual retirement age in EU member states, early and late 2000s

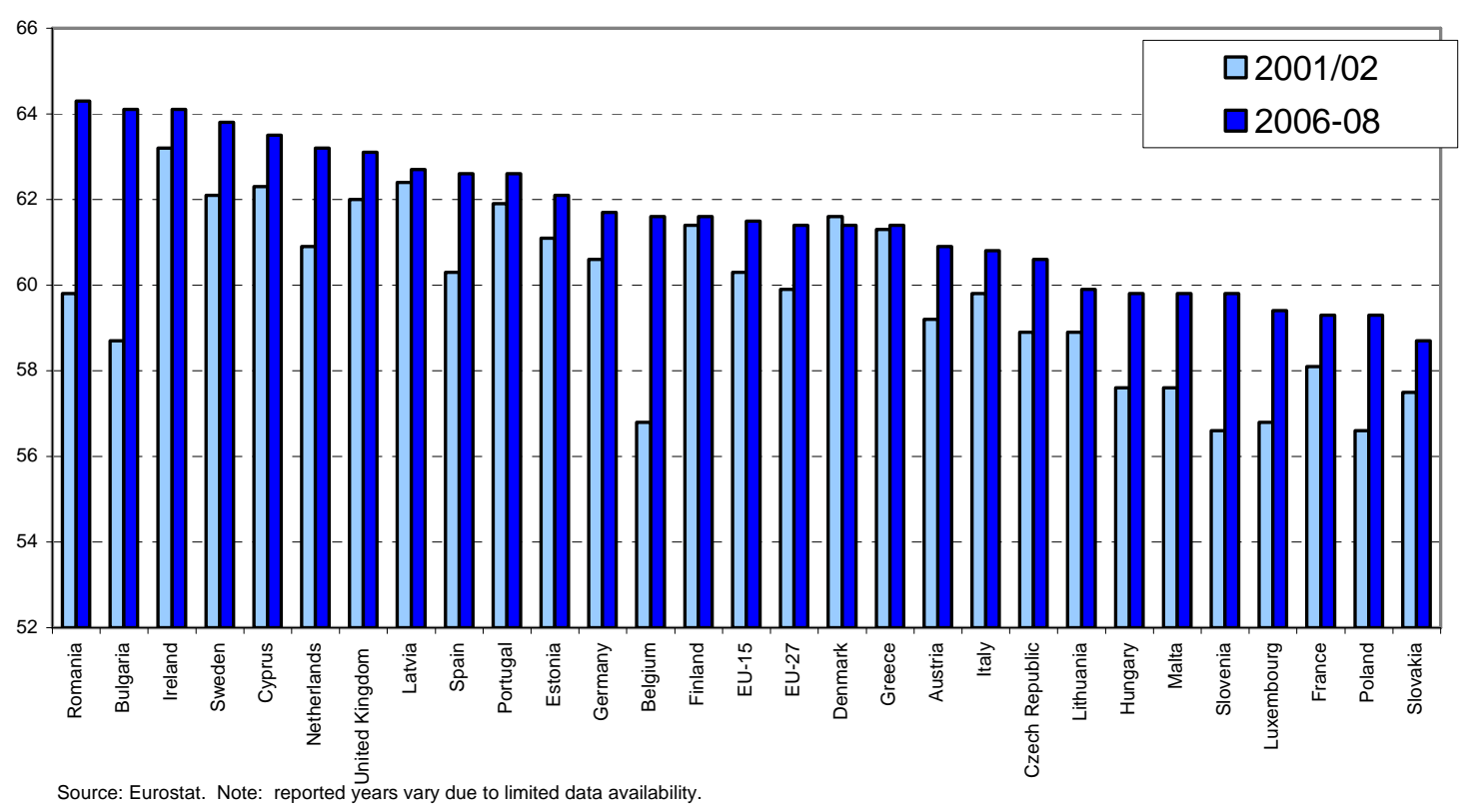

Yet despite some convergence towards higher employment of older workers and later actual retirement, there are still significant and persistent differences in the employment situation of older workers in the EU. More active ageing is far from being a universal phenomenon in EU member states.

While one can observe successes and failures in postponing retirement and raising employment rates of older workers and still identify a common trend, diversity is even more pronounced and persistent in participation in lifelong learning than in employment rates or retirement ages - although lifelong learning is seen as a cornerstone of a European strategy enabling workers to cope with changing labor market conditions and technological progress. However, this may be explained by problems how lifelong learning activities are reported. The EU has set a target of 12.5 percent by 2020 for average participation in lifelong learning for adults aged 25 to 64. Figure 3 shows to what extent EU member states have met this target. Despite some increase in most EU member states, only a few of them have been able to achieve the target, in particular the Scandinavian countries, the UK, the Netherlands, Austria and Slovenia as well as Luxembourg. The EU-15 average grew from 8 to 11 percent, the EU-27 average from 7 to 9 percent. ' Some countries such

\footnotetext{
${ }^{1}$ According to this definition, lifelong learning refers to individuals aged 25 to 64 who reported having received education or training in the four weeks preceding the survey.
} 
as Germany have achieved higher employment of older workers without much emphasis on adult learning.

Figure 3: Lifelong learning participation of 25-64 year olds in the EU

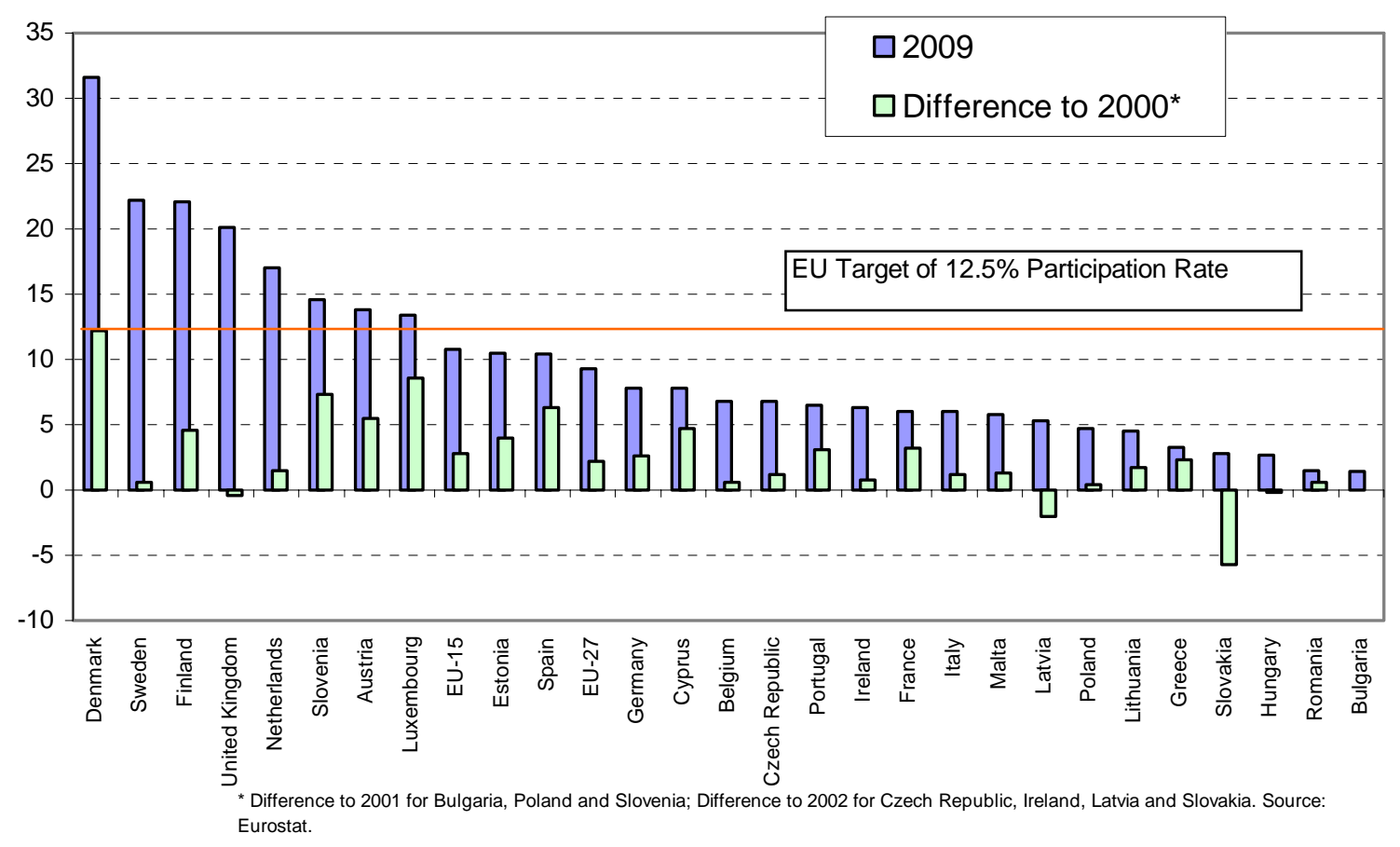

\section{Explaining diversity}

\subsection{The role of incentives and behavior}

What drives older workers' employment rates and their average retirement age? Strong and long-standing changes in employment patterns cannot be ascribed to business cycle variations. Institutional variables as well as behavioral factors matter and interact with each other, as incentives stemming from institutional arrangements influence actors' behavior and actors' demands for certain policies influence the design or change of existing institutions.

Earlier studies from the late 1990s had, in particular, addressed the issue of retirement incentives stemming from social benefits (Blöndal/Scarpetta 1998, Gruber/Wise 1998). Recent comparative work by OECD researchers (Bassanini/Duval 
2006) confirms this institutionalist view. It also shows that the removal of early retirement incentives, a later statutory retirement age as well as less generous unemployment benefits and lower income taxes and non-wage labor costs, i.e. tax wedges, all lead to higher employment rates of older workers. Dismissal protection can also stabilize employment of incumbent older workers if not offset by early retirement incentives. Hence, differences in employment rates across countries and over time can to a large extent be explained by institutional variation.

Institutional settings that can provide pathways out of the labor market do not only concern specific early retirement schemes but also options to receive old-age pensions at an early stage such as disability pensions, extended unemployment benefits for older workers, long-term sickness benefits and a number of other pathways to retirement such as old-age part-time work. Furthermore, there is strong interaction between early retirement policies and a discouragement of older workers' participation in job-related training (OECD 2006). The earlier workers leave the labor market, the less likely they are to participate in continuous vocational education (Bassanini et al. 2007). Active labor market policies can constitute an additional bridge to early exit from the labor market if such schemes are used to lower registered unemployment without a realistic chance of reintegration into regular employment. Limiting access to benefits and implementing stronger activation policies can, in turn, be expected to increase retirement age and employment levels of older workers as well as employees' participation in job-related training. Hence, incentives from social and labor market policies can either facilitate or postpone early withdrawal from the labor market.

Retirement incentives, however, affect the core labor force with a substantial employment and social insurance record in particular, so that substantial benefits can be received during retirement. Hence, the removal of such incentives can lead to higher labor force participation of older workers, in particular male labor market 'insiders'. Finally, behavioral factors can also matter independently from retirement schemes. This is particularly true for the stronger labor market attachment of younger cohorts of women. As more labor market-affiliated cohorts of women age, the employment/population ratio of older workers rises.

\subsection{The politics of early retirement}

Early retirement was implemented in many European countries, mostly Continental or Bismarckian countries, in the 1970 s and the 1980 s as a policy to contain unemployment in a situation of weak economic growth and massive deindustrialization. At that time, it was perceived as a socially acceptable policy facilitating smooth economic restructuring (Hemerijck/Eichhorst 2010, Palier 2010) in conjunction with a rejuvenation of the labor force and continually low open unemployment. This came, however, at the price of rising non-wage labor costs in those social insurance systems which heavily relied on this policy instrument. 
Establishing early retirement policies is one thing - removing them is a different issue. Creating routes for early exit not only lowers firms' and workers' propensity to maintain employability via training, it also changes the public discourse and firm staffing routines. First, from the perspective of policy makers and the wider public, early retirement policies tend to suggest that a fixed "lump of labor" is to be preserved and redistributed to young labor market entrants by removing older workers from labor force (Kemmerling 2007). Second, from the perspective of firms, early retirement is a convenient solution to rejuvenate the labor force and raise productivity while at the same time avoiding costs for continuous vocational training. However, restricting training to younger people in a situation where older workers are expected to leave employment early tends to reinforce stereotypes about a general decline of productivity and employability with age which, in turn, also lowers the propensity of older workers to be hired after a phase of unemployment. So the assumption of limited employability of older workers can become a self-fulfilling prophecy, which can be used to justify the continuation of early retirement policies. Third, when certain cohorts are entitled to leave the labor market at a premature age, younger cohorts tend to expect that they will be equally entitled to retire early basically for fairness reasons, as early retirement is perceived as an acquired right.

Hence, early retirement can become, at least for a certain period, a self-stabilizing routine policy response that is hard to overcome. This was particularly apparent in Bismarckian countries, where such policies were considered a panacea of smooth and socially acceptable adjustment to economic change for more than two decades (Hemerijck/Eichhorst 2010).

Major pressure to change this policy setting does not come from the labor market but from the welfare state, in particular fiscal pressure due to rising expenditure for non-employed older workers and a deterioration of the revenue side due to stagnant employment and negative effects of increasing non-wage labor costs and taxes on job creation. Moving beyond the early retirement equilibrium, therefore, is a particularly difficult and contentious issue, as it entails a redistribution of costs and benefits to the detriment of older cohorts of workers in manufacturing or the public sector close to retirement, who make up large shares of the trade union rank-and-file. Modifying and abolishing popular, deeply entrenched programs and policies that interact across policy areas and have mostly long-term beneficial effects on labor market behavior is challenging from the perspective of policy makers. Researchers, therefore, have pointed at the crucial contribution of institutional and politico-economic factors in explaining departures from early retirement (Ebbinghaus 2006 and 2010, Bonoli/Palier 2007, Immergut/Anderson 2007, Hartlapp/Kemmerling 2008) where both governments' and social partners' strategies play crucial roles as well as the institutional features of the political system. As regards to the design of policies encouraging a higher labor force participation of older worker by removing early retirement, recent research has not shown major differences across partisan orientation in European governments. Rather, socio- 
economic pressure in terms of rising non-wage labor costs and pressure on public budgets is to be seen as the major driving force behind contentious and mostly unpopular policies (Vis 2009). However, the actual reform process can take different directions depending on actors' behavior and institutional preconditions.

Regarding institutions, it does matter to what extent governments are in control of social protection and exit pathways and to what extent social partners can pursue autonomous or compensatory early retirement policies in this context. In a situation where the social partners have strong influence on benefit generosity and access to social insurance or can counterbalance government-imposed changes in benefit rules via collective agreements, some corporatist agreement is conducive to a timely policy reversal. If governments and social partners can agree on a coordinated policy change, a swift and more comprehensive policy reversal becomes feasible, especially if cuts in social benefits are compensated for by some supportive measures (see e.g. the Finnish case).

An alternative strategy governments can pursue is a more stepwise approach whereby state-controlled policy areas are modified which, in turn, changes the incentives for employers and employees for early retirement. Less public support to early retirement makes premature exit less attractive to workers and more costly to employers. This, in turn, leads to adjustments in actors' behavior, thereby paving the way for further changes encouraging more active ageing. To avoid blame, a typical element used in the area of pension reform, and also in the phasing-out of early retirement, changes typically only concern younger cohorts, so that current pensioners or older workers close to retirement are not affected. As a consequence, considerable time lags are most characteristic for this approach (Bonoli/Palier 2010). But compensatory enterprise- or sector-level policies in the area of early retirement will become ever more costly to maintain, so that early retirement pursued by the social partners loses ground in the long run.

There is one major risk attached to the sequential government-driven closure of early retirement. Moving beyond an early retirement equilibrium requires coordination across different areas of social protection and labor market policies, as full policy reversal requires the closure of different pathways towards early retirement, such as early exit via old-age pensions, long and non-activating unemployment insurance benefits, as well as through disability and sickness insurance or specific retirement-oriented active labor market policy programs. With the progressive closure of some early exit pathways, for example in old-age pensions, alternative exit routes which are still available become more popular. So while reform processes maybe quite consensual in pensions, restricting access to alternative pathways, in particular to the last remaining "sacred cows" in the national context can imply a major societal conflict, in particular in countries with an extensive early retirement culture, such as France, Austria, the Netherlands, Italy and Belgium (see Hemerijck/Eichhorst 2010, Palier 2010). However, even in countries with a continually high employment rate of older workers and strong emphasis on lifelong learning, such as Denmark or Sweden, some early retirement policies are still in place. 
This can only be overcome by government imposition shifting costs to firms and employees, since incorporating the social partner in the design of policies could lead to policy reform deadlock. One case in point is the reform of disability pensions in the Netherlands or the difficult and protracted path towards later retirement in France.

Supranational influence such as the targets and policy recommendations from the European Employment Strategy or the Lisbon Process can play a role in the national context, which is, however, still to be seen as dominant when it comes to actually reforming pensions and labor market policies. Decisive parameters driving or limiting the employment of older workers are set in the national context. The actual influence of the European level is, however, hard to identify (Zeitlin 2005). A broad and general move towards later retirement and higher employment of older workers observed across EU member states is not necessarily proof of an effective EU monitoring process. Given the lack of clear evidence in favor of a decisive role of EU recommendations, it can at best be conceived as a "selective amplifier" of some policy strategies pursued at the national level (Visser 2005). European targets and recommendations can be used as additional amplifying arguments to advance reforms furthering the employment of older workers and remove work disincentives by national policy makers to emphasize their policy orientation when deemed suitable. But "European" requirements are difficult to put forward if there is strong opposition at the national level and a widely shared belief that early retirement is still viable or desirable.

\section{Towards a longer working life: The German case}

\subsection{Early exit policies}

Based on this comparative analysis, an in-depth study of the German case can shed further light on the dynamics of policy change regarding the abolition of early retirement policies and its consequences for the labor market. The German case is

of particular relevance, not only because Germany has tried to stabilize its labor market and production model through early retirement for more than 20 years; it is also one of the most striking cases of a dramatic increase in the employment of older workers over the last decade. This relative medium-run success was achieved despite a persistent lack of institutional prerequisites facilitating policy coordination across policy areas and between government and social partners at the national level.

Starting in the 1970s, the German case used to be a typical example of an extensive Continental European labor shedding strategy. Explicit early retirement was introduced in the 1970s and expanded significantly in the 1980s in order to avoid a massive increase in open unemployment and stabilize the German production re- 
gime in a situation of industrial restructuring. This implied a number of measures, such as the early receipt of public pensions at the age of 63, or even earlier in some cases (flexible Altersgrenze), starting in 1972, and the introduction of a specific early retirement schemes (Vorruhestand) in 1984, which provided subsidies for early retirement if young people were hired. Furthermore, in the 1980s receipt of unemployment insurance benefits (Arbeitslosengeld) was expanded to up to 32 months for older workers. Starting in the 1970 s older workers aged 59 and over were not subject to availability for job placement anymore after one year of unemployment. This age limit was lowered to 57 in 1987; in addition, as was the case in the past, means-tested, but status-related, unemployment assistance (Arbeitslosenhilfe) could be received for an unlimited period of time after the expiry of unemployment insurance benefits, without any activity requirements. Disability pensions taking into account professional achievement (Berufsunfähigkeitsrente) provided another alternative early exit from the labor market. In 1989 subsidized old-age part-time work (Altersteilzeit) was introduced. It was expected to facilitate a gradual transition to retirement while encouraging labor market entry of young people, thereby modifying the old early retirement scheme. In practice it meant additional public support for retirement before the transition to old-age pensions as employers and employees chose to combine a first phase of full-time work and a second phase of fulltime retirement instead of a flexible phasing out of employment.

Policies encouraging early exit from work were expanded until the mid-1990s, with a final peak after reunification to avoid skyrocketing open unemployment in East Germany after massive de-industrialization. This referred to subsidized short-time work and a special transition allowance (Altersübergangsgeld). Furthermore, the 1990 s were characterized by a more permissive payment of old-age part-time work subsidies. The use of this tool was further encouraged by establishing a specific subsequent pathway to pensions (Altersrente nach Altersteilzeit) in 1996.

\subsection{A fundamental turn-around in retirement policies}

However, while early retirement was perceived as a smooth and beneficial social policy approach to industrial restructuring, the costs attached to this strategy became apparent in the aftermath of German reunification. The most important manifestation was a steep increase in the number of working-age people relying on benefits. As the schemes were mainly funded via social insurance, this development was associated with a massive increase in contribution rates and non-wage labor costs. The total contribution rate to German social insurance increased from 30.5 percent in 1975 to 39.3 percent in 1995 and 42.1 percent in 1998 (Hinrichs 2010). Furthermore, demographic projections signaled a long-term deterioration of the old-age dependency ratio. Due to longer life expectancy, the number of older people was expected to rise, while the working-age population would shrink dramatically. Under given institutional conditions, this would lead to growing con- 
tribution rates for public old-age pension insurance, thereby pushing up non-wage labor costs even further.

In a situation where the German economy faced increasing global competition, raising prices for German goods was less of an alternative in the 1990s than in the past. Hence, stabilizing or even reducing non-wage labor costs was perceived not only by business as an important step to restore competitiveness. This change in perception paved the way for policies to consolidate social insurance schemes.

The policy shift was first laid down in the pension reforms of 1989/92, 1996/97 and 1999, with the actual phase in starting between 1992 and 2004 (see Schulze/Jochem 2007, Hinrichs 2010). These reforms made early withdrawal from the labor market less attractive, as monthly pensions were reduced in the case of early access to old-age pensions. Early receipt of pensions for women, after a long working life, unemployment or old-age part-time work, as well as for disabled people, was made subject to discounts, i.e. a maximum of three to five years of early pension receipt would imply up to 10.8 percent or 18 percent lower monthly pensions on a permanent basis. Furthermore, the regular access age for full pensions after unemployment or old-age part-time work, for women and disabled and after long contributory periods were to be raised in a stepwise manner from 60 or 63 to 65.

Raising premature retirement ages in combination with the introduction of significant discounts made early retirement via the old-age pension system less attractive for employees. Given strong dismissal protection, which makes redundancies quite difficult and costly, this also implied that firm restructuring became more expensive. Severance pay for older workers would have to compensate for less generous public social benefits, in particular if it is credited against unemployment benefits.

Related to the general pension reform adopted in 1999, and effective as of 2001, disability pensions based on professional achievements (Berufsunfähigkeitsrente) were abolished for younger cohorts and replaced by a much less attractive regime based on the assumption that some capacity to work in any job or occupation has to be exploited before access to disability pensions is granted (Enwerbsminderungsrente). This reform has basically closed the pathway to retirement via occupationspecific disability and shifted this risk to private insurance.

Referring to the general and dominant concern for the sustainability of public pensions and the stability of contribution rates, the German public old-age pension system departed from status-protecting benefits with intermediate consequences for the younger cohorts. These can only expect benefits substantially below the level of public pensions received by older cohorts. A complementary step in this direction was stronger public support for employer-related and private pension schemes, i.e. for the second and the third pillar of pension regimes. The most prominent scheme is the so-called Riester Rente which provides for a state subsidy for private savings in a certified savings scheme. 
Table 1: Major reforms affecting older workers after reunification in Germany, 1990-2009

\begin{tabular}{|c|c|c|}
\hline Year & Reform & $\begin{array}{l}\text { Expected ef- } \\
\text { fect on em- } \\
\text { ployment of } \\
\text { older workers } \\
\text { and retire- } \\
\text { ment age }\end{array}$ \\
\hline 1990 & $\begin{array}{l}\text { Transitory payment for older unemployed aged } 57 \text { and older } \\
\text { (Altersübergangsgeld) }\end{array}$ & - \\
\hline 1991 & $\begin{array}{l}\text { Transitory payment for older unemployed aged } 55 \text { and older } \\
\text { for a maximum of } 5 \text { years }\end{array}$ & - \\
\hline \multicolumn{3}{|c|}{ ( } \\
\hline 1993 & $\begin{array}{l}\text { Severance pay credited against unemployment insurance } \\
\text { benefit (phased-in 1995); transition form transitory payment } \\
\text { to pension system enforced }\end{array}$ & $+/=$ \\
\hline 1994 & $\begin{array}{l}\text { Relaxed conditions for old-age part-time work (Altersteilzeit), } \\
\text { receipt of unemployment insurance benefit without availabil- } \\
\text { ity for work expanded; expansion of wage subsidies for hiring } \\
\text { older workers }\end{array}$ & $-/+$ \\
\hline \multicolumn{3}{|c|}{ ( } \\
\hline 1996 & $\begin{array}{l}\text { Reform of old-age part-time work aimed at discouraging early } \\
\text { retirement and encouraging gradual retirement; access to } \\
\text { public pensions after old-age part-time work; further changes } \\
\text { in retirement ages and early pension receipt }\end{array}$ & $+/-$ \\
\hline 1997 & $\begin{array}{l}\text { More restricted access to longer unemployment insurance } \\
\text { benefits for older workers; stricter crediting of severance pay- } \\
\text { ments against unemployment insurance benefits (to be } \\
\text { phased in 1999); further changes in retirement ages and early } \\
\text { pension receipt }\end{array}$ & + \\
\hline 1998 & Further prolongation of old-age part-time work & - \\
\hline 1999 & $\begin{array}{l}\text { Stricter crediting of severance payments against unemploy- } \\
\text { ment insurance benefits revoked; further changes in retire- } \\
\text { ment ages and early pension receipt; abolition of occupation- } \\
\text { based disability insurance for younger cohorts; replacement } \\
\text { by less generous scheme (Erwerbsminderungsrente) effective as } \\
\text { of } 2001\end{array}$ & + \\
\hline 2000 & $\begin{array}{l}\text { Prolongation of and relaxed access to old-age part-time work; } \\
\text { receipt of unemployment insurance benefit without availabil- } \\
\text { ity for work expanded }\end{array}$ & - \\
\hline \multicolumn{3}{|c|}{ e } \\
\hline \multicolumn{3}{|l|}{2002} \\
\hline 2003 & Innovative active labor market programs such as earnings in- & + \\
\hline
\end{tabular}

2"+" indicates an expected rise in the employment or retirement age of older workers, "-" a decline and "=" a neutral or unclear effect. If in a given year opposing reforms are observed, different signs are assigned. 


\begin{tabular}{|c|c|c|}
\hline Year & Reform & $\begin{array}{l}\text { Expected ef- } \\
\text { fect on em- } \\
\text { ployment of } \\
\text { older workers } \\
\text { and retire- } \\
\text { ment age }\end{array}$ \\
\hline & $\begin{array}{l}\text { surance, exemption from employer contributions, new hiring } \\
\text { subsidies and relaxed conditions for fixed-term contracts for } \\
\text { older workers (some measures only with limited existence) }\end{array}$ & \\
\hline 2004 & $\begin{array}{l}\text { Shortening of unemployment insurance benefit for older } \\
\text { workers (phased-in 2006); minor reform of old-age part-time } \\
\text { work }\end{array}$ & + \\
\hline 2005 & $\begin{array}{l}\text { Entry into force of Hartz IV (abolition of status-related un- } \\
\text { employment assistance, replacement by flat-rate benefit Ar- } \\
\text { beitslosengeld II); receipt of unemployment insurance benefit } \\
\text { without availability for work expanded }\end{array}$ & $+/-$ \\
\hline \multicolumn{3}{|c|}{ ( } \\
\hline 2007 & $\begin{array}{l}\text { Increase of regular pension age to } 67 \text { (to be phased in after } \\
\text { 2012); within the framework of a broader initiative (Ini- } \\
\text { tiative 50plus) a range of active schemes is expanded }\end{array}$ & + \\
\hline 2008 & $\begin{array}{l}\text { Longer maximum unemployment insurance benefit receipt for } \\
\text { older workers }\end{array}$ & - \\
\hline 2009 & Expiry of subsidized old-age part-time work & + \\
\hline
\end{tabular}

Source: author's compilation based on Steffen (2009).

\subsection{Towards activation of older workers}

In 1999, within the framework of the tripartite Alliance for Jobs, trade unions called for access to old-age pensions at 60 (Rente mit 60). This was not supported by the government at the time, but did lead to a further expansion of old-age parttime work. Yet the preferential treatment of older workers in terms of benefit access became more critical around the turn of the decade, also with some reference to the recently launched European Employment Strategy and the Lisbon Process which was observed more intensely at the time. However, when it came to concrete reforms, policy makers in Germany did not make systematic reference to European or supranational recommendations. With the Hartz report of 2002 providing a blueprint for a wide range of labor market reforms, the next step of institutional change was introduced. While the original Hartz Commission's report, influenced heavily by the perspective of a large manufacturing employer, advocated a special early retirement benefit (Brückengeld), the actual reform package implemented between 2003 and 2005 stressed the activating side of labor market policies.

With Agenda 2010, announced in March 2003, most reforms were designed to cut public social expenditure (Eichhorst/Marx 2011). One element was a shorter maximum duration of unemployment insurance benefits (Arbeitslosengeld I) for 
older workers of up to 18 months instead of 32 months. This was phased in February 2006 but, after strong public debate, modified again in early 2008, so that unemployed aged 58 and older can now claim unemployment insurance benefits for up to 24 months, 15 months if 50 and older and 18 months if at least 55 . Nevertheless, prolonging older workers' unemployment insurance benefit cannot be seen as a decisive policy reversal, it is rather an exceptional step due to particular party-political discourses at the time. However, it mirrored a widely shared uneasiness with the departure from status-oriented social benefits which were implemented in early 2005 with the Hartz IV reform abolishing status-related unemployment assistance and introducing a general minimum incomes support scheme for all those of working-age (Arbeitslosengeld II). This not only meant less generous benefits for unemployment assistance beneficiaries with a substantial employment record, but also stronger means-testing and stricter activation efforts (Eichhorst/Grienberger-Zingerle/Konle-Seidl 2010).

However, activation of older unemployment benefit recipients is still limited. Until 2007, unemployed aged 58 and older were able to withdraw from the unemployment register without losing their benefit entitlement if they applied for full pensions at the earliest moment. This was replaced by a provision exempting claimants of (much less generous) minimum income support from availability for job placement after one year of no activation and placement efforts. In general, this reform means that older workers have fewer opportunities to withdraw from the labor force with attractive conditions and to reject activation measures while continuing to receive benefits.

Emphasis on reemploying older workers has grown over time, but the role of active labor market policies and activation strategies is certainly less decisive than the changes implemented in benefit provisions. A number of demand- and supply-side measures have been promoted in recent years (see Eichhorst 2006). First, conditions for hiring unemployed aged 52 and older on fixed-term contracts were relaxed in 2003, along with the introduction of reinforced wage subsidies to employers and an exemption of firms hiring workers aged 55 and older from employer contributions to unemployment insurance. Second, an earnings insurance scheme was implemented in order to make employment at lower entry wages more attractive to older unemployed (Entgeltsicherung). Finally, publicly subsidized training was promoted for older workers in smaller firms. Most of these measures, such as the wage subsidies and further training for older workers, were expanded within the framework of a broader initiative launched in 2007 (Initiative 50plus). Compared to the changes in the benefits systems, however, the contribution of active labor market policies for older workers was quite limited, as was shown in the take-up of these schemes and the findings from evaluation studies. Consequently, some of the measures introduced with the Hartz package were later abolished.

One of the last and most important steps mirroring a change in public discourse was the announcement in late 2006 to move the standard retirement age from 65 to 67 for cohorts born 1947 and later, and moving the minimum age for early pen- 
sion receipt to 65 with related discounts. This is to be phased-in in a stepwise manner between 2012 and 2029. The main motivation, once again, was to try to stablize both the contribution rates and the pension level in a situation of demographic ageing. Shifting the statutory retirement age to 67 goes beyond what was in place or considered in most EU member states.

\subsection{The changing perception of the retirement issue}

Hence, a major policy turn-around occurred in the 1990s, before the European Employment Strategy and the Lisbon Strategy have even been launched. Major conflicts were avoided, not by references to supranational recommendations or targets, but by long phase-in periods, which are typical for changes in pension systems. Older cohorts of workers, which were well organized in the German trade unions and often employed in large manufacturing firms heavily relying on early retirement, were practically unaffected by the policy changes. German policy makers did not develop an integrated strategy for active ageing; rather, they reacted to current fiscal problems in the welfare state and projected effects of demographic change.

Based on the observation of significant increases in the employment rate of the elderly in the second half of the 2000s, the public perception of older workers' position on the labor market reached a certain tipping point. Early retirement was no longer perceived as a "necessary" policy instrument to keep unemployment low and allow for a better integration of young people into the labor market. Both actors' behavior and public discourse are fundamentally different from the late 1990s. Encouraging early retirement has become basically a non-topic nowadays. The idea of a fixed "lump of labor" is perceived as a thing of the past and hardly mentioned anymore in mainstream public debate. Removing older workers in order to improve labor market access of young people is no longer seen as a plausible policy - in particular given demographic change and strong increases in overall employment. Hence, publicly subsidized old-age part-time work, one of the last remaining subsidized pathways to early retirement, ended for new entrants to the scheme in late 2009 without much public attention (apart from some calls for prolongation from the trade unions of the relevant sectors). Even the difficult economic situation in the most recent recession did not lead to relevant calls for a reintroduction of early retirement schemes. There is only some trade union concern about certain professions not being able to reach retirement at 67 . Accordingly, a delayed retirement age for some occupations will practically result in a reduced pension level. Notwithstanding some criticism of the increased retirement age, the German government could confirm the definitive introduction of this change in late 2010 (Bundesministerium für Arbeit und Soziales 2010).

This is not to say that at the sectoral or enterprise-level early exit policies do not exist any more. Early exit and also old-age part-time work can still be negotiated by 
sectoral or firm-level social partners. But a cumulative sequence of changes in social and labor market policies have taken away the most attractive exit routes, as now either employers or workers have to bear most of the costs of such strategies. Hence, nowadays the scope of these policies is much more limited, and will remain so in the future. For example, old-age part-time work is now based on a revised collective agreement in the metal working sector with restricted access and limited generosity.

Contrasting the reform activity in the area of social benefits, there is still very low emphasis on lifelong learning in a more systematic way. This holds in particular for low-skilled and older workers, who tend to be the most vulnerable groups when it comes to obsolete skills in a situation of technological and sectoral change.

Table 2: Participation in lifelong learning by age groups in Germany, in \%

\begin{tabular}{|cccccccr|}
\hline & & 1991 & 1994 & 1997 & 2000 & 2003 & 2007 \\
\hline \multirow{3}{*}{ Total } & $19-35$ & 44 & 49 & 53 & 47 & 46 & 46 \\
& $35-50$ & 40 & 47 & 54 & 49 & 46 & 47 \\
& $50-64$ & 23 & 28 & 36 & 31 & 31 & 34 \\
\hline \multirow{3}{*}{ General adult learning } & $19-35$ & 25 & 30 & 35 & 29 & 29 & 30 \\
& $35-50$ & 24 & 29 & 33 & 29 & 27 & 28 \\
& $50-64$ & 15 & 19 & 26 & 21 & 20 & 23 \\
\hline \multirow{3}{*}{ Job-related adult learning } & $19-35$ & 25 & 27 & 33 & 31 & 29 & 27 \\
& $35-50$ & 24 & 29 & 36 & 36 & 31 & 31 \\
& $50-64$ & 11 & 14 & 20 & 18 & 17 & 19 \\
\hline
\end{tabular}

Source: Bundesministerium für Arbeit und Soziales 2010.

In this context, German policy makers have not referred systematically to country experiences with stronger participation of the labor force in continuous education. One reason of very limited attempts to increase general access to job-related training is the fragmentation of funding and responsibilities. Quite in contrast to countries like Denmark or Sweden with a highly developed public infrastructure contributing to more general further education of the employed, job-related training in Germany is mainly organized and funded by employers. It is therefore related to current human resource requirements. Given the strong emphasis on employers' responsibilities for further training, public initiatives within the framework of either the educational sector or active labor market policies have never gained ground. Only recently has there been some emphasis on the further education of (currently employed) low-skilled and older workers, funded by German unemployment insurance. Otherwise, publicly subsidized training in the framework of active labor market policy has always been (and still is) focused on the unemployed. However, this 
element met strong criticisms in the early 2000s and was reorganized in a more selective way in order to meet stricter performance criteria. Given the most recent German public discourse dominated by the issue of skills shortages, policy makers will eventually take up this topic.

\subsection{Employment dynamics of older workers}

The overall employment rate of older workers has increased dramatically and more vigorously than for younger workers since the late 1990s, in particular for workers aged 60 to 62 (see table 3). At the same time, however, this development is characterized by a certain degree of dualization. On the one hand, the continued employment of older workers, in particular skilled employees, has grown in importance alongside the removal of early retirement incentives. This group would have benefited from early exit in the past, but as this strategy has become more costly and the number of skilled labor market entrants has been declining, a longer working life is now increasingly more common. On the other hand, less-skilled older workers do not benefit from this trend towards a longer working life. Recent research has shown that in some occupations, employment records of workers aged 55 and over are less stable (Brussig 2010a, 2010b). Notwithstanding this, employment covered by social insurance has grown substantially in recent years, whereas the share of non-standard employment (i.e. part-time, marginal employment, fixed-term contracts and agency work) has basically remained stable for older workers.

While continuing employment seems to become a general strategy for skilled workers with specific human capital in a situation of a declining number of younger labor market entrants, reemployment of older workers after a phase of unemployment is still more problematic (Brussig 2009). Hence, it seems fair to say that there is some dualization between older labor market 'insiders' with a solid employment record and people in a more vulnerable position. This can also be seen from the fact that the number of rehired older workers is relatively small. However, one should not take the increase in open unemployment of older workers due to the removal of premature exit routes within the social benefit arrangement as a sign of a deterioration of their situation. 
Table 3: Employment levels and structures of older workers by age groups, 2000-2009

\begin{tabular}{|c|c|c|c|c|c|c|c|c|c|c|c|}
\hline & 2000 & 2001 & 2002 & 2003 & 2004 & 2005 & 2006 & 2007 & 2008 & 2009 & \\
\hline \multicolumn{11}{|c|}{ Employment/population ratio by age } & $\begin{array}{l}\text { Change } \\
\text { in per- } \\
\text { centage } \\
\text { points }\end{array}$ \\
\hline $20-55$ & 77.7 & 77.9 & 77.0 & 76.1 & 74.9 & 75.1 & 76.6 & 78.1 & 78.8 & 78.5 & 0.8 \\
\hline $55-60$ & 56.5 & 57.7 & 59.4 & 60.0 & 61.1 & 63.3 & 64.2 & 66.5 & 68.6 & 69.9 & 13.4 \\
\hline $60-65$ & 19.9 & 21.3 & 22.7 & 23.4 & 25.1 & 28.1 & 29.6 & 32.8 & 35.0 & 38.4 & 18.5 \\
\hline $60-61$ & 29.4 & 33.4 & 36.7 & 39.9 & 41.2 & 43.3 & 43.9 & 46.7 & 48.8 & 51.8 & 22.4 \\
\hline 61-62 & 24.2 & 25.0 & 27.6 & 29.9 & 34.6 & 37.0 & 37.7 & 40.2 & 42.8 & 44.8 & 20.6 \\
\hline $62-63$ & 19.9 & 20.5 & 21.6 & 22.7 & 24.5 & 30.6 & 32.5 & 34.6 & 36.3 & 38.9 & 19.0 \\
\hline $63-64$ & 12.7 & 15.0 & 15.6 & 16.0 & 17.7 & 20.2 & 22.7 & 26.0 & 26.2 & 28.6 & 15.9 \\
\hline 64-65 & 10.3 & 10.7 & 11.8 & 12.0 & 12.6 & 14.7 & 17.0 & 19.1 & 21.3 & 22.3 & 12.0 \\
\hline \multicolumn{11}{|c|}{ Employed covered by social insurance in \% of age group } & \\
\hline $20-55$ & 58.5 & 58.8 & 57.9 & 56.7 & 55.8 & 55.0 & 55.4 & 56.2 & 57.4 & 56.8 & -1.7 \\
\hline $55-60$ & 43.8 & 43.4 & 43.0 & 42.7 & 42.5 & 41.5 & 42.8 & 44.6 & 46.6 & 48.3 & 4.5 \\
\hline $60-65$ & 10.9 & 11.6 & 12.8 & 13.5 & 15.0 & 16.6 & 17.1 & 18.7 & 20.6 & 23.4 & 12.5 \\
\hline \multicolumn{11}{|c|}{ Share of non-standard workers in \% of all employed in the respective age group } & \\
\hline $20-55$ & 12.8 & 12.9 & 12.7 & 13.2 & 13.2 & 14.4 & 15.9 & 16.5 & 16.5 & 16.2 & 3.4 \\
\hline $55-60$ & 9.3 & 9.7 & 10.1 & 10.5 & 10.4 & 11.0 & 12.2 & 12.6 & 13.0 & 13.3 & 4.0 \\
\hline $60-65$ & 4.3 & 4.8 & 5.3 & 5.3 & 5.4 & 6.2 & 6.6 & 7.2 & 7.7 & 7.9 & 3.6 \\
\hline \multicolumn{11}{|c|}{ Share of older workers in newly hired employed covered by social insurance in \% } & \\
\hline & 8.7 & 9.2 & 9.9 & 10.1 & 10.2 & 10.3 & 10.7 & 11.1 & 11.7 & 12.9 & 4.2 \\
\hline
\end{tabular}

Source: Bundesministerium für Arbeit und Soziales 2010. 
In conclusion, the German case shows a more sequential, sometimes even contradictory, pattern of reforms. Considerations for the stability of the public pension system as well as contribution rates dominated the public discourse. There was only marginal reference to European targets and policy monitoring. However, with hindsight, one can identify a crucial role of changes in pension rules with a long phase-in period regarding actual pension entitlements but with some medium-run effects on firms' and workers' retirement behavior. Later on, further adjustment in the area of unemployment benefits and active labor market policies became possible. This stepwise approach reduced the level of societal conflicts, as one policy change opened up occasions for further steps. Furthermore, this strategy allowed for changes in actors' behavior, in particular employment practices of firms, as well as collective agreements which have eventually resulted in a strong recovery of the employment prospects of older workers. When exit becomes more costly to firms and workers, human resource policies at the enterprise level change. Together with less generous and later pension payments for younger cohorts the policy shift towards activation and means-tested income support implied the closure of virtually all non-activating status-related early retirement options. However, this has so far meant mostly continuous employment of workers who would have otherwise left earlier rather than a better reintegration of older unemployed people and stronger and more universal emphasis on lifelong learning. 


\section{Conclusion}

The analysis shows that institutional factors are very important in determining the transition from work to retirement. Following a phase of massive early retirement in the 1970 s and the 1980s, there has been since the late 1990s a major policy reversal in EU member states to reduce incentives for early withdrawal from the labor force and raise the employment rate of older workers. A major element has been the modification of social benefits in combination with the introduction of activation policies. In empirical terms, this has led to general trend towards postponing retirement and some approximation to the EU targets regarding retirement age and employment levels of older workers. Differences across countries still persist, both regarding the institutional pathways to retirement and in the actual retirement behavior of older workers as actors' behavior responds to incentives from public social and labor market policies. Hence, one should not overestimate the harmonizing influence of the European Employment Strategy and the Lisbon Process on national policies and performance. A general trend towards later retirement is not a strong piece of evidence in favor of convergence induced by European level activities. Rather, politico-economic factors deeply entrenched in the national political arena are essential when it comes to explaining policy persistence and reversal. Taking the German case as an example, it can be shown that fiscal concerns regarding the welfare state created strong incentives to phase out early retirement and to raise the employment level of older workers. Hence, national-level actors' strategies and political institutions are most important in explaining concrete policy changes. Countries with heavy reliance on early retirement can successfully embark on the road to stronger labor market integration of older workers if either a coordinated or a stepwise, sequential approach is adopted. The latter, in turn, opens up opportunities for subsequent reforms which are facilitated by changes in the behavior of workers and firms. EU targets and policy recommendations can be seen as "selective amplifiers" in this context. However, the national policy arena is the most dominant forum when it comes to explaining policy change. Although the situation of older people in the German labor market improved basically in parallel with the development of integrated European policy guidelines and targets, this does not justify a causal claim about strong EU influence on policy making in Germany. 


\section{References}

Bassanini, Andrea/Duval, Romain (2006): Employment Patterns in OECD Countries: Reassessing the Role of Policies and Institutions. OECD Economics Department Working Paper 486. Paris: OECD.

Bassanini, Andrea/Booth, Alison/Brunello, Giorgio/De Paola, Maria/Leuven, Edwin (2007): Workplace Training in Europe. In: Brunello, Giorgio/Garibaldi, Pietro/Wasmer, Etienne (eds): Education and Training in Europe. Oxford: Oxford University Press, 143-289.

Blöndal, Sveinbjörn/Scarpetta, Stefano (1998): The Retirement Decision in OECD Countries. OECD Economics Department Working Paper 202. Paris: OECD.

Bonoli, Giuliano/Palier, Bruno (2007): When Past Reforms Open New Opportunities: Comparing Old-Age Insurance Reforms in Bismarckian Welfare Systems. Social Policy and Administration 41 (6), 555-573.

Brussig, Martin (2010a): Erwerbstätigkeit im Alter hängt vom Beruf ab: Ausdifferenzierung der Erwerbschancen vor allem nach dem 60. Lebensjahr, in einigen Berufen aber schon früher. Altersübergangsreport 2010-05. Duisburg: IAQ.

Brussig, Martin (2010b): Höhere Alterserwerbsbeteiligung durch längere Erwerbsphasen: In jüngeren Kohorten sind mehr Menschen länger erwerbstätig als in älteren Kohorten. Altersübergangsreport 2010-04. Duisburg: IAQ.

Brussig, Martin (2009): Neueinstellungen von Älteren: Keine Ausnahme, aber auch noch keine Normalität - Anhaltende Altersungleichheit bei Neueinstellungen trotz zunehmender Beschäftigungsquoten Älterer. Altersübergangsreport 200901. Duisburg: IAQ.

Bundesministerium für Arbeit und Soziales (2010): Aufbruch in die altersgerechte Arbeitswelt: Bericht der Bundesregierung gemäß $\S 154$ Abs. 4 Sechstes Buch Sozialgesetzbuch zur Anhebung der Regelaltersgrenze auf 67 Jahre. Berlin: BMAS.

Ebbinghaus, Bernhard (2010): Reforming Bismarckian Corporatism: The Changing Role of Social Partnership in Continental Europe. In: Palier, Bruno (ed.): A Long Goodbye to Bismarck: The Politics of Welfare Reform in Continental Europe. Amsterdam: Amsterdam University Press, 255-278.

Ebbinghaus, Bernhard (2006): Reforming Early Retirement in Europe, Japan and the USA. Oxford: Oxford University Press.

Ebbinghaus, Bernhard/Eichhorst, Werner (2009): Germany. In: de Beer, Paul/Schils, Trudie (eds): The Labour Market Triangle: Employment Protection, Unemployment Compensation and Activation in Europe, Cheltenham: Edward Elgar, 119-144. 
Eichhorst, Werner (2006): Beschäftigung Älterer in Deutschland: Der unvollständige Paradigmenwechsel. Zeitschrift für Sozialreform/Journal of Social Policy Research $52(1), 101-123$.

Eichhorst, Werner/Grienberger-Zingerle, Maria/Konle-Seidl, Regina (2010): Activation Policies in Germany: From Status Protection to Basic Income Support. German Policy Studies, 6 (1), 59-100.

Eichhorst, Werner/Marx, Paul (forthcoming, 2011): Reforming German Labor Market Institutions: A Dual Path to Flexibility. Journal of European Social Policy 21 (1).

European Commission (2010): Indicators for Monitoring the Employment Guidelines Including Indicators for Additional Employment Analysis. 2010 Compendium.

Gruber, Jonathan/Wise, David W. (1998): Social Security Programs and Retirement Around the World. Research in Labor Economics 18, 1-40.

Hartlapp, Miriam/Kemmerling, Achim (2008): When a Solution Becomes the Problem: The Causes of Policy Reversal on Early Exit from the Labour Force. Journal of European Social Policy 18 (4), 366-379.

Hemerijck, Anton/Eichhorst, Werner (2010): Whatever Happened to the Bismarckian Welfare State? From Labor Shedding to Employment-Friendly Reforms. In: Palier, Bruno (ed.): A Long Goodbye to Bismarck: The Politics of Welfare Reform in Continental Europe. Amsterdam: Amsterdam University Press, 301-332.

Hinrichs, Karl (2010): A Social Insurance State Withers Away. Welfare State Reforms in Germany - Or: Attempts to Turn Around in a Cul-de-Sac. In: Palier, Bruno (ed.): A Long Goodbye to Bismarck: The Politics of Welfare Reform in Continental Europe. Amsterdam: Amsterdam University Press, 45-72.

Immergut, Ellen M./Anderson, Karen M. (2007): Editors' Introduction: The Dynamics of Pension Politics. In: Immergut, Ellen M./Anderson, Karen M./Schulze, Isabelle (eds): The Handbook of West European Pension Politics. Oxford: Oxford University Press, 1-45.

Kemmerling, Achim (2007): The End of Work or Work Without End? The Role of Voters' Beliefs in Shaping Policies of Early Exit. WZB Discussion Paper SP I 2007-108.

OECD (2006): Live Longer, Work Longer. Paris: OECD.

Palier, Bruno (2010): The Long Consenvative Corporatist Road to Welfare Reforms. In: Palier, Bruno (ed.): A Long Goodbye to Bismarck: The Politics of Welfare Reform in Continental Europe. Amsterdam: Amsterdam University Press, 333-387. 
Schulze, Isabelle/Jochem, Sven (2007): Germany: Beyond Policy Gridlock. In: Immergut, Ellen M./Anderson, Karen M./Schulze, Isabelle (eds): The Handbook of West European Pension Politics. Oxford: Oxford University Press, 660-710.

Steffen, Johannes (2009): Sozialpolitische Chronik: November 2009. Bremen: Arbeitnehmerkammer.

Vis, Barbara (2009): The Importance of Socio-Economic and Political Losses and Gains in Welfare State Reform. Journal of European Social Policy 19 (5), 395407.

Visser, Jelle (2005): The OMC as Selective Amplifier for National Strategies of Reform. What the Netherlands Want to Learn from Europe. In: Zeitlin, Jonathan/Pochet, Philippe/Magnusson, Lars (eds): The Open Method of Coordination in Action: The European Employment and Social Inclusion Strategies. Brussels: PIE-Peter Lang, 173-216.

Zeitlin, Jonathan (2005): The Open Method of Co-ordination in Action: Theoretical Promise, Empirical Realities, Reform Strategy. In: Zeitlin, Jonathan/Pochet, Philippe/Magnusson, Lars (eds.): The Open Method of Coordination in Action: The European Employment and Social Inclusion Strategies. Brussels: PIE-Peter Lang, 447- 503. 